ఠ

\title{
Dronabinol oral solution in the management of anorexia and weight loss in AIDS and cancer
}

This article was published in the following Dove Press journal:

Therapeutics and Clinical Risk Management

\section{Melissa E Badowski \\ Paa Kwesi Yanful}

Section of Infectious Diseases Pharmacotherapy, Department of Pharmacy Practice, University of Illinois at Chicago, College of Pharmacy, Chicago, IL, USA
Correspondence: Melissa E Badowski Section of Infectious Diseases Pharmacotherapy, Department of Pharmacy Practice, University of Illinois at Chicago, 833 S. Wood, M/C 886, Room

164, Chicago, IL, 606I2, USA

$\mathrm{Tel}+\mathrm{I} 3124131674$

Fax +I 3123552823

Email badowski@uic.edu

\begin{abstract}
The true incidence of anorexia secondary to human immunodeficiency virus (HIV)/acquired immunodeficiency syndrome (AIDS) and cancer is not well classified owing to the fact that there is a lack of standardized definitions and recent clinical data in these settings. Dronabinol, or $\Delta$-9-tetrahydrocannabinol, is a synthetic molecule that closely mimics the action of Cannabis sativa L., a naturally occurring compound activated in the central nervous system by cannabinoid receptors. Dronabinol exerts its effects by directly acting on the vomiting and appetite control centers in the brain, which in turn increases appetite and prevents vomiting. In the USA, dronabinol is currently available in two dosage formulations - oral capsule and oral solution. While the oral capsule was initially approved by the US Food and Drug Administration in 1985, the recent approval of the oral solution in 2016 presents an "easy-to-swallow" alternative for patients using or intending to use dronabinol. Dronabinol is indicated in adult patients with HIV/AIDS for the treatment of anorexia and weight loss. However, there is no approved indication in the setting of cancer-related anorexia and weight loss. This review aims at presenting available data on the use of oral dronabinol in the management of anorexia and weight loss in HIV/AIDS and cancer, as well as characterizing and highlighting the pharmacotherapeutic considerations of the newest formulation of dronabinol.
\end{abstract}

Keywords: HIV/AIDS, cancer, anorexia, weight loss, cachexia, dronabinol

\section{Introduction}

The definition of human immunodeficiency virus (HIV)/acquired immunodeficiency syndrome (AIDS) wasting through time and the appreciable need for adequate pharmacologic treatment in patients who still experience anorexia have been discussed extensively. ${ }^{1-3}$ Yet, the actual prevalence of HIV wasting in patients receiving modernized antiretroviral therapy is not well defined. However, the most recent data suggest the estimated prevalence of HIV wasting rests anywhere between $14 \%$ and $38 \%{ }^{3}$ Similarly, anorexia is estimated to be present in up to $25 \%$ of patients at the time of cancer diagnosis and in $26 \%$ of patients receiving chemotherapy. ${ }^{4,5}$ The true incidence of anorexia secondary to HIV/AIDS and cancer is not well classified due to the lack of standardized definitions and recent clinical data in these settings.

Dronabinol, or $\Delta$-9-tetrahydrocannabinol (THC), is a synthetic form of THC that mimics the action of the naturally occurring Cannabis sativa L., which is activated in the central nervous system (CNS) by cannabinoid receptors (CB). Although dronabinol has a similar affinity to $\mathrm{CB} 1$ and $\mathrm{CB} 2, \mathrm{CB} 1$ is primarily responsible for producing appetite stimulation when activated. ${ }^{6}$ Dronabinol directly acts in the vomiting and appetite control centers in the brain, thereby increasing appetite and preventing vomiting. ${ }^{7}$ Along with its appetite-stimulating properties, it also produces affective, sensory, somatic, and cognitive effects in the CNS and has central sympathomimetic activity. 
The synthetic form of THC received initial US Food and Drug Administration approval in 1985 as an oral capsule formulation, but was recently approved in 2016 as an oral solution with the aim of presenting an "easy-to-swallow" alternative for patients using or intending to use dronabinol capsules. $^{8-10}$ In patients with nausea and vomiting, this could be crucial, as it may be easier to swallow a solution compared to a capsule. While dronabinol is indicated in adults for the treatment of anorexia-associated weight loss in patients with HIV/AIDS, there is no approved indication in the setting of anorexia-associated weight loss in patients with cancer. Its clinical utility in the oncology population has been approved as an agent to combat chemotherapy-induced nausea and vomiting (CINV) in patients failing to respond to conventional antiemetics, which may ultimately impact body weight and food intake.

This review will specifically focus on the utility of oral dronabinol in the management of anorexia and weight loss in AIDS and cancer. In addition, pharmacotherapeutic considerations of dronabinol oral solution will also be highlighted.

\section{Materials and methods}

English language articles available from PUBMED and Google Scholar were searched through September 15, 2017. The following search terms were used to identify pertinent articles: " $\Delta$-9-tetrahydrocannabinol”, "cannabinoid”, “dronabinol", "dronabinol oral solution", "dronabinol oral capsule”, "Marinol", "Syndros", "marijuana", "HIV", "HIV/AIDS", "AIDS", "cancer", "malignancy", “oncology", "cachexia”, "anorexia", "weight loss", "pharmacokinetics", "pharmacodynamics", "efficacy", and "safety". Additional publications were identified through reviewing references from publications retrieved using the aforementioned search terms.

\section{Dronabinol experience in the HIV/AIDS population}

Loss of appetite in patients living with HIV/AIDS are thought to be due to difficulty in chewing and swallowing secondary to stomatitis, intermittent or chronic diarrhea, and opportunistic infections such as cytomegalovirus, microsporidia, and cryptosporidium. ${ }^{11}$ Increased appetite in the setting of anorexia secondary to HIV/AIDS is a vital clinical goal as enhanced appetite has been linked to substantially improved quality of life. ${ }^{12}$ Some studies have reported that in patients with AIDS, weight loss was associated with relatively poor outcomes. ${ }^{13,14}$ Dronabinol oral capsule has been used in these settings to increase appetite since its approval by the US Food and Drug Administration in May $1985 .{ }^{15}$ One study published in 1997 reported that throughout a 12-month study period, the percentage change in appetite from baseline in the dronabinol group was $48.6 \%-76.1 \%$ compared to $27.3 \%-69.9 \%$ in the placebo group. The study also reported that during the initial 7 months, patients in the dronabinol arm maintained or showed an increase in weight from 0.4 up to $1.3 \mathrm{~kg} .{ }^{11}$

Previous studies have explored the use of oral dronabinol capsules in patients living with HIV/AIDS for the management of anorexia and cachexia and reported that the change in total body weight ranged from -2.0 to $3.2 \mathrm{~kg}$, whereas in placebo-controlled studies, the change in total body weight for those in the placebo arm ranged from -0.7 to $1.1 \mathrm{~kg}$. The data have been extensively reviewed elsewhere. ${ }^{1}$

Incidentally, most studies evaluating the use of dronabinol excluded patients who were current users of marijuana. This presents a challenge as patients living with HIV/AIDS are one of the largest groups that use cannabinoids medicinally. Furthermore, a considerable amount of patients living with HIV currently smoke marijuana. ${ }^{16}$ Therefore, excluding such patients may present challenges in the overall provision of care, as it has been reported that the prevalence of marijuana smoking intended for HIV-associated benefits is around $23 \% .{ }^{17}$ Haney et al discussed the effects of dronabinol and smoked marijuana on food in marijuana smokers living with HIV. In this double-blind, placebo-controlled study of 10 marijuana smokers with HIV, patients were assigned to dronabinol $5 \mathrm{mg}$, dronabinol $10 \mathrm{mg}$, or smoked marijuana (3.9\%) four times daily for 4 days. Patients were evaluated over two 16-day inpatient phases with a 4-day placebo washout period between phases. The study found that when compared to placebo, both oral dronabinol and smoked marijuana increased daily caloric intake $(p<0.008$ and $p<0.01$, respectively), but did not significantly alter the performance on assigned tasks (ie, vigilance, methods of learning, psychomotor ability, and memory). ${ }^{16}$ While high doses of dronabinol safely increased the caloric intake, it is important to note that higher doses may be required in patients who smoke marijuana, as repeated subsequent high doses of dronabinol appeared to elicit tolerance as reported in this study. ${ }^{18}$

\section{Dronabinol experience in the cancer population}

Patients with a cancer diagnosis often suffer from cachexia, which clinically manifests as weight loss with anorexia, as well as weakness, inflammation, insulin resistance, and progressive loss of fat and muscle. ${ }^{4}$ This phenomenon is thought to be due to metabolic changes caused by tumors, 
cytokines, and endogenous substances, and is associated with reduced quality of life and response to chemotherapy as well as a prognostic indicator. Based on the lack of a universal definition of cachexia in cancer patients, this complication remains underdiagnosed and undertreated. One study used four different definitions to classify cachexia among cancer patients and found a wide variation in the incidence based on the definition used: 1) International Classification of Diseases, Ninth Revision diagnostic code for cachexia $(2.4 \%)$; $)$ expanded International Classification of Diseases, Ninth Revision codes cachexia, anorexia, abnormal weight loss, or feeding difficulties (5.5\%); 3) prescription for megestrol acetate, oxandrolone, somatropin, or dronabinol $(6.4 \%)$; or 4$) \geq 5 \%$ weight loss $(14.7 \%)$. ${ }^{19}$ More importantly, cancer-induced cachexia is estimated to be the immediate cause of death in as many as $40 \%$ of cancer patients. ${ }^{20}$

Although recent studies have not evaluated the use of dronabinol oral solution in this setting, its indication is based on previous studies leading to the approval of dronabinol capsules as well as the recently published bioequivalence data (Table 1). ${ }^{8,21}$ Many clinical studies evaluating the use of dronabinol are based in the setting of CINV, yet comment on the dronabinol's effect on oral intake or weight. One study evaluating the role of THC and prochlorperazine as an antiemetic in patients receiving chemotherapy demonstrated increased food intake in the THC group $(p=0.008)$, whereas other studies did not find such an association. ${ }^{22-25}$

Most clinical studies conducted on dronabinol use, in the setting of anorexia, were performed many years ago using varying definitions to classify anorexia. Research performed by Plasse et al evaluated 42 cancer patients for up to 6 weeks with varying doses of dronabinol in two multicenter, open, and dose-ranging studies on appetite stimulation (Table 1). ${ }^{26}$ No significant weight gain was observed between the treatment arms, yet reduction in the rate of weight loss $(2.5 \mathrm{mg}$ daily compared to $5 \mathrm{mg}$ daily) and increased appetite scores (2.5 mg twice daily

Table I Bioequivalence and cancer-associated anorexia or weight loss data

\begin{tabular}{|c|c|c|c|c|c|c|c|}
\hline Study & Population & $\begin{array}{l}\text { Duration } \\
\text { (weeks) }\end{array}$ & $\begin{array}{l}\text { Total number } \\
\text { of patients }\end{array}$ & Treatment groups $(n)$ & $\begin{array}{l}\text { Pertinent clinical } \\
\text { outcomes }\end{array}$ & $\begin{array}{l}\text { Adverse } \\
\text { events }\end{array}$ & $\begin{array}{l}\text { Discontinued } \\
\text { due to } A E\end{array}$ \\
\hline \multicolumn{8}{|c|}{ Bioequivalence data } \\
\hline $\begin{array}{l}\text { Parikh } \\
\text { et al, } \\
2016\end{array}$ & $\begin{array}{l}\text { Healthy } \\
\text { volunteers }\end{array}$ & 4 & $\begin{array}{l}\text { 5I (crossover } \\
\text { study) }\end{array}$ & $\begin{array}{l}\text { Dronabinol oral solution: } \\
4.25 \mathrm{mg} \text { daily }(\mathrm{n}=5 \mathrm{I}) \\
\text { Dronabinol capsule: } \\
5 \mathrm{mg} \text { daily }(\mathrm{n}=5 \mathrm{I})\end{array}$ & $\begin{array}{l}\text { Dronabinol PK (Replicate I) } \\
C_{\max } \text { (ng/mL) } \\
\text { - Soln: I.8I } \\
\text { - Cap: } 2.20 \\
T_{\max } \text { (hours) } \\
\text { - Soln: } 1.5 \\
\text { - Cap: } 1.0 \\
\text { AUC }_{0-\infty} \text { (hours } \times \mathrm{ng} / \mathrm{mL} \text { ) } \\
\text { - Soln: } 3.75 \\
\text { - Cap: } 3.85 \\
t_{1 / 2} \text { (hours) } \\
\text { - Soln: } 5.41 \\
\text { - Cap: } 2.68\end{array}$ & $\begin{array}{l}\text { Nausea, } \\
\text { dizziness, } \\
\text { somnolence, } \\
\text { headache }\end{array}$ & None \\
\hline $\begin{array}{l}\text { Oh } \\
\text { et al, } \\
2017\end{array}$ & $\begin{array}{l}\text { Healthy } \\
\text { volunteers }\end{array}$ & 2 & $\begin{array}{l}54 \text { (crossover } \\
\text { study) }\end{array}$ & $\begin{array}{l}\text { Dronabinol oral solution: } \\
4.25 \mathrm{mg} \text { daily }(\mathrm{n}=52) \\
\text { Dronabinol capsule: } \\
5 \mathrm{mg} \text { daily }(\mathrm{n}=54)\end{array}$ & $\begin{array}{l}\text { Dronabinol PK (Fed) } \\
T_{\text {lag }} \text { (hours) } \\
\text { - Soln: } 0.15(\mathrm{CV}=49.3 \%) \\
\text { - Cap: } 2.02(\mathrm{CV}=70.2 \%) \\
T_{\max } \text { (hours) } \\
\text { - Soln: } 7.67(\mathrm{CV}=44.7 \%) \\
\text { - Cap: } 5.59(\mathrm{CV}=58 \%) \\
C_{\max } \text { (ng/mL) } \\
\text { - Soln: } 1.52(\mathrm{CV}=63.5 \%) \\
\text { - Cap: } 2.60(\mathrm{CV}=67.1 \%) \\
\text { AUC } C_{0-\infty}(\mathrm{hours} \times \mathrm{ng} / \mathrm{mL}) \\
\text { - Soln: } 10.25(\mathrm{CV}=36.9 \%) \\
\text { - Cap: I2.2। (CV=39.6\%) } \\
t_{1 / 2} \text { (hours) } \\
\text { - Soln: } 9.35(\mathrm{CV}=71.9 \%) \\
\text { - Cap: } 10.4(\mathrm{CV}=88.7 \%)\end{array}$ & $\begin{array}{l}\text { Headache, } \\
\text { euphoric } \\
\text { mood }\end{array}$ & None \\
\hline
\end{tabular}


Table I (Continued)

\begin{tabular}{|c|c|c|c|c|c|c|c|}
\hline Study & Population & $\begin{array}{l}\text { Duration } \\
\text { (weeks) }\end{array}$ & $\begin{array}{l}\text { Total number } \\
\text { of patients }\end{array}$ & Treatment groups (n) & $\begin{array}{l}\text { Pertinent clinical } \\
\text { outcomes }\end{array}$ & $\begin{array}{l}\text { Adverse } \\
\text { events }\end{array}$ & $\begin{array}{l}\text { Discontinued } \\
\text { due to AE }\end{array}$ \\
\hline \multicolumn{8}{|c|}{ Cancer-associated anorexia or weight loss data ${ }^{26-29}$} \\
\hline $\begin{array}{l}\text { Plasse } \\
\text { et al, } \\
|99|^{b}\end{array}$ & Cancer & $\begin{array}{l}\text { Study I: } 3 \\
\text { Study 2: } 6\end{array}$ & 42 & $\begin{array}{l}\text { Dronabinol capsule } \\
2.5 \mathrm{mg} \text { daily }(\mathrm{n}=8) \\
\text { Dronabinol capsule } \\
2.5 \mathrm{mg} \text { BID }(\mathrm{n}=9) \\
\text { Dronabinol capsule } 5 \mathrm{mg} \\
\text { daily }(\mathrm{n}=19) \\
\text { Dronabinol capsule } \\
2.5 \mathrm{mg} \text { BID }(\mathrm{n}=6)\end{array}$ & $\begin{array}{l}\text { Increased appetite: } \\
\text { - A trend of increased } \\
\text { appetite was noted from } \\
\text { baseline in } 2.5 \mathrm{mg} \text { BID } \\
\text { group ( } p=0.08 \text { ) } \\
\text { - } 2.5 \mathrm{mg} \text { BID group } \\
\text { was associated with } \\
\text { improved appetite when } \\
\text { compared to } 2.5 \text { or } 5 \mathrm{mg} \\
\text { daily ( } p<0.05 \text { ) } \\
\text { Weight gain/change: } \\
\text { - No significant weight } \\
\text { gain between groups } \\
\text { - Reduction in the rate of } \\
\text { weight loss was found } \\
\text { between } 2.5 \text { and } 5 \mathrm{mg} \\
\text { daily ( } p<0.05 \text { ) }\end{array}$ & $\begin{array}{l}\text { Dizziness, } \\
\text { memory or } \\
\text { mood changes, } \\
\text { psychotropic } \\
\text { effects }\end{array}$ & $\begin{array}{l}\text { I0 (24\%) } \\
\text { I in each } \\
\text { dronabinol } 2.5 \mathrm{mg} \\
\text { daily and BID and } \\
\text { the remainder in } \\
\text { higher doses }\end{array}$ \\
\hline $\begin{array}{l}\text { Nelson } \\
\text { et al, }{ }^{27} \\
1994\end{array}$ & Cancer & 4 & 18 & $\begin{array}{l}\text { Dronabinol capsule } \\
2.5 \mathrm{mg} \text { TID }(\mathrm{n}=18)\end{array}$ & $\begin{array}{l}\text { Improved appetite: } \\
\text { - I3 of } 18 \text { patients }\end{array}$ & $\begin{array}{l}\text { Slurred } \\
\text { speech, nausea }\end{array}$ & 3 \\
\hline $\begin{array}{l}\text { Jatoi } \\
\text { et al, }{ }^{28} \\
2002\end{array}$ & Cancer & Varied & 469 & $\begin{array}{l}\text { Megestrol acetate: } \\
800 \text { mg daily }(n=I 59) \\
\text { Dronabinol capsule: } \\
2.5 \text { mg BID ( } n=I 52) \\
\text { Megestrol acetate } \\
800 \text { mg daily+dronabinol } \\
\text { capsule } 2.5 \text { mg BID: } \\
(n=I 58)\end{array}$ & $\begin{array}{l}\text { Increased appetite: } \\
\text { - } 75 \% \text { megestrol acetate } \\
\text { vs } 49 \% \text { dronabinol } \\
(p=0.000 \text { I }) \\
\text { - } 75 \% \text { megestrol acetate } \\
\text { vs } 66 \% \text { megestrol } \\
\text { acetate+dronabinol } \\
\text { ( } p=0.17) \\
\text { Weight gain: } \\
\text { - II } \% \text { megestrol acetate } \\
\text { vs } 3 \% \text { dronabinol } \\
\text { ( } p=0.02) \\
\text { - I } \% \text { megestrol acetate } \\
\text { vs } 8 \% \text { megestrol } \\
\text { acetate+dronabinol } \\
\text { ( } p=0.43)\end{array}$ & $\begin{array}{l}\text { Impotence: } \\
\text { I8\% megestrol } \\
\text { acetate vs } \\
4 \% \text { dronabinol } \\
(p=0.002) \\
\text { Other effects } \\
\text { NS difference }\end{array}$ & $\begin{array}{l}\text { Megestrol acetate: } \\
45 \% \\
\text { Dronabinol: } 58 \% \\
\text { Megestrol } \\
\text { acetate+dronabinol: } \\
41 \%\end{array}$ \\
\hline $\begin{array}{l}\text { Strasser } \\
\text { et al, }{ }^{29} \\
2006\end{array}$ & Cancer & 6 & 243 & $\begin{array}{l}\text { CE BID: }(n=95) \\
\text { Dronabinol: } 2.5 \text { mg BID } \\
(n=100) \\
\text { Placebo: BID }(n=48)\end{array}$ & $\begin{array}{l}\text { Increased appetite: } \\
\text { - CE: } 73 \% \\
\text { - Dronabinol: } 58 \% \\
\text { - Placebo: } 69 \% \text { ( } p=\mathrm{NS} \\
\text { between the groups) }\end{array}$ & NS difference & Not reported \\
\hline
\end{tabular}

Notes: ${ }^{a}$ Data on the use of dronabinol in HIVIAIDS appetite stimulation previously reviewed. ${ }^{1-3}$ b Data reported as combined.

Abbreviations: AE, Adverse event; AIDS, acquired immunodeficiency syndrome; $\mathrm{AUC}_{0-\infty}$, area under the plasma concentration-time curve from time zero to infinity; $\mathrm{AUC}_{0-\mathrm{t}}$, area under the plasma concentration-time curve from time zero to the last measurable concentration; BID, twice daily; Cap, capsule; CE, Cannabis extract (dronabinol $2.5 \mathrm{mg}+$ cannabidiol I mg); $C_{\max }$, peak plasma concentration; CV, intraindividual coefficient of variability; HIV, human immunodeficiency virus; NS, not significant; PK, pharmacokinetics; Soln, solution; $t_{1 / 2}$, half-life; TID, three times daily; $T_{\text {lag }}$, time to the first measurable concentration; $T_{\text {max }}$, time to maximum plasma concentration.

[BID] compared to 2.5 and $5 \mathrm{mg}$ daily) were observed. Borderline significance, as related to dronabinol's effect on mood, was reported between $2.5 \mathrm{mg}$ BID and $2.5 \mathrm{mg}$ daily $(p=0.06)$ as well as between 2.5 and $5 \mathrm{mg} \operatorname{BID}(p=0.05)$. Psychotropic effects were documented in four patients receiving $2.5 \mathrm{mg}$ BID, eight patients receiving $5 \mathrm{mg}$ daily, and two patients receiving $5 \mathrm{mg}$ BID. No patients reported any effects in the group receiving $2.5 \mathrm{mg}$ daily. One part of the study excluded the use of chemotherapy, but the authors did not specify which treatment arm(s) were impacted. This was a major limitation to the study, along with inconsistent sample size between groups. Based on their findings, the authors concluded that dronabinol $2.5 \mathrm{mg}$ BID stimulated appetite and improved mood. 
A Phase II study evaluated the use of THC in patients with advanced cancer anorexia between March 1990 and July 1991 (Table 1). ${ }^{27}$ Patients received oral dronabinol capsules for 4 weeks. Most patients reported appetite improvement, with a median weight gain of $1.3 \mathrm{~kg}$ (range: $1-2.7 \mathrm{~kg}$ ). One patient reported weight loss of $6.7 \mathrm{~kg}$. Although the study population was rather small and the dose of dronabinol was low, dronabinol appeared to be an effective appetite stimulant and was well tolerated in patients with advanced cancer.

Another study evaluated a slightly lower dose of dronabinol compared to megestrol acetate or the two agents used in combination in the management of cancer-associated anorexia between December 1996 and December 1999 (Table 1). ${ }^{28}$ Patients were eligible for participation if they reported decreased appetite or $\geq 2.3 \mathrm{~kg}$ weight loss over 2 months and/or a daily intake $<20$ calories $/ \mathrm{kg}$ of body weight. Although megestrol acetate was found to have a more profound effect in appetite stimulation, the dose of dronabinol was relatively low but well tolerated. Even at such a low dose, dronabinol improved appetite in nearly $50 \%$ of patients with comparable toxicities between the groups.

The most recent clinical trial in this setting evaluated cannabis extract, dronabinol, or placebo in patients with cancer-related anorexia-cachexia syndrome. ${ }^{29}$ The study was conducted between October 1999 and September 2002, and included patients who had advanced incurable cancer and an involuntary weight loss of $\geq 5 \%$ within the past 6 months (Table 1). No significant differences in appetite, body weight, quality of life, or toxicity occurred between the treatment arms. Therefore, the study was terminated due to lack of differences between the treatment arms.

Based on the available data, there is a definite need for a standardized definition of cancer-related anorexia-cachexia. In addition, the paucity of recent data demonstrates the renewed need to complete further research in this area as well as on dronabinol oral solution and other cannabis formulations.

\section{Bioequivalence studies}

To date, two studies have evaluated the pharmacokinetic parameters of dronabinol oral solution vs dronabinol oral capsule. ${ }^{8,21}$ The first study evaluated the pharmacokinetic parameters under fasting conditions, whereas the second study evaluated them under fed conditions, using a fasted state as its control. Both studies were conducted in healthy volunteers and excluded participants with medical conditions, including pregnancy, as well as volunteers who abused substances, including marijuana and alcohol. However, the timeframe in which patients who abused substances could be eligible for inclusion varied between the studies. In Oh et al's study, patients were excluded if they have had history or potential for substance abuse within the past 1 year. ${ }^{8}$ Participants were eligible for inclusion if they were aged between 18 and 50 years and weighed at least $60 \mathrm{~kg}$. On the contrary, marijuana use was permitted at least 90 days prior to inclusion in Parikh et al's study, but history of all other forms of substance abuse within the past 10 years was not allowed. ${ }^{21}$ Participants were included if they were aged $18-55$ years and weighed at least $50 \mathrm{~kg}$.

The study by Parikh et al was a randomized, open-label, crossover study that assessed the bioavailability of dronabinol oral solution vs oral capsule. ${ }^{21}$ Two outcomes were analyzed in the study - the pharmacokinetic profile and the safety profile of the oral solution when compared to the oral capsule. Pharmacokinetic parameters assessed included $T_{\max }$, $C_{\max }, t_{1 / 2}$, area under the plasma concentration-time curve from time zero to the last measurable concentration $\left(\mathrm{AUC}_{0-t}\right)$, and area under plasma concentration-time curve from time zero to infinity $\left(\mathrm{AUC}_{0-\infty}\right)$, as shown in Table 2 . In a post hoc analysis, the intraindividual variabilities calculated for $\mathrm{AUC}_{0-\infty}$ were lower and in favor of the $4.25 \mathrm{mg}$ dronabinol oral solution compared with the $5 \mathrm{mg}$ dronabinol capsule, suggesting that the oral solution may have more predictable pharmacokinetics. It was reported that the $\mathrm{AUC}_{0-t}$ and $\mathrm{AUC}_{0-\infty}$ for dronabinol was within the bioequivalence range $(80 \%-125 \%)$ when oral solution was compared to oral capsule. The median $T_{\max }$ of dronabinol was shorter for the oral solution compared to that of the capsule. The mean half-life was also longer for dronabinol oral solution when compared to oral capsule, indicating that the oral solution took shorter time to reach peak concentrations of dronabinol and stayed in the body longer than the capsule formulation. Caution must be exercised when choosing which formulation to use. While patients with urgent needs may benefit from the quicker time to peak concentrations with the oral solution, it may take longer to rid patients of the drug, should the need arise in the setting of intolerable adverse effects. The authors also reported that the frequencies of adverse drug events between the two formulations were similar.

A Phase I, single-dose, randomized, open-label trial aimed to evaluate the bioavailability of dronabinol oral solution when compared to the oral capsule. ${ }^{8}$ This study was not intended to assess bioequivalence as comparative bioequivalence of the two dosage forms had previously been demonstrated. ${ }^{21}$ This study assessed the following outcomes - comparative bioavailability of both dosage forms 
Table 2 Pharmacotherapy and pharmacokinetic considerations with dronabinol9,10

\begin{tabular}{|c|c|c|}
\hline & Dronabinol oral capsule ${ }^{9}$ & Dronabinol oral solution ${ }^{10}$ \\
\hline Dosage forms & - $2.5,5$, and $10 \mathrm{mg}$ capsules & - $5 \mathrm{mg} / \mathrm{mL}$ solution \\
\hline Storage & $\begin{array}{l}\text { - Packaged in a well-closed container } \\
\text { - Stored in a cool environment between } 8^{\circ} \mathrm{C} \text { and } 15^{\circ} \mathrm{C} \\
\left(46^{\circ} \mathrm{F} \text { and } 59^{\circ} \mathrm{F}\right) \\
\text { - Can be refrigerated, but not frozen }\end{array}$ & $\begin{array}{l}\text { - Keep solution and syringe in the supplied carton } \\
\text { - Refrigerated between } 2^{\circ} \mathrm{C} \text { and } 8^{\circ} \mathrm{C}\left(36^{\circ} \mathrm{F} \text { and } 46^{\circ} \mathrm{F}\right) \\
\text { - Opened bottle can be stored at room temperature } \\
25^{\circ} \mathrm{C}\left(77^{\circ} \mathrm{F}\right) \\
\text { - Discard unused portion } 28 \text { days after first opening }\end{array}$ \\
\hline Initial dose (adults) & $\begin{array}{l}\text { - Anorexia-associated weight loss in adults with AIDS: } \\
2.5 \mathrm{mg} \text { PO BID, I hour before lunch and dinner } \\
\text { - } \mathrm{CINV} \text { in adults failing conventional antiemetics: } \\
5 \mathrm{mg} / \mathrm{m}^{2} \mathrm{PO} \text { I-3 hours prior to chemotherapy, then } \\
\text { every } 2-4 \text { hours after chemotherapy, not to exceed } \\
\text { six doses/day. First dose should be taken on an empty } \\
\text { stomach and subsequent doses may be taken without } \\
\text { regards to meals }\end{array}$ & $\begin{array}{l}\text { - Anorexia-associated weight loss in adults with AIDS: } \\
2 . I \mathrm{mg} \text { PO BID, I hour before lunch and dinner } \\
\text { - CINV in adults failing conventional antiemetics: } \\
4.2 \mathrm{mg} / \mathrm{m}^{2} \mathrm{PO} \text { I-3 hours prior to chemotherapy, then } \\
\text { every } 2-4 \text { hours after chemotherapy, not to exceed } \\
\text { six doses/day. First dose should be taken on an empty } \\
\text { stomach and subsequent doses may be taken without } \\
\text { regards to meals }\end{array}$ \\
\hline $\begin{array}{l}\text { Initial dose (elderly } \\
\text { and patients unable to } \\
\text { tolerate initial dosing } \\
\text { recommendations) }\end{array}$ & $\begin{array}{l}\text { - Anorexia-associated weight loss in adults with AIDS: } \\
2.5 \mathrm{mg} \text { PO once daily I hour before dinner or bedtime } \\
\text { - CINV in adults failing conventional antiemetics: } \\
2.5 \mathrm{mg} / \mathrm{m}^{2} \text { once daily I-3 hours prior to chemotherapy }\end{array}$ & $\begin{array}{l}\text { - Anorexia-associated weight loss in adults with AIDS: } \\
2.1 \mathrm{mg} \text { PO once daily I hour before dinner or bedtime } \\
\text { - CINV in adults failing conventional antiemetics: } \\
2.1 \mathrm{mg} / \mathrm{m}^{2} \text { once daily I-3 hours prior to chemotherapy }\end{array}$ \\
\hline Maximum dose & $\begin{array}{l}\text { - Anorexia-associated weight loss in adults with AIDS: } \\
10 \mathrm{mg} \text { BID } \\
\text { - } \mathrm{CINV} \text { in adults failing conventional antiemetics: } \\
\mathrm{I} 5 \mathrm{mg} / \mathrm{m}^{2} \text { per dose, not exceeding six doses/day }\end{array}$ & $\begin{array}{l}\text { - Anorexia-associated weight loss in adults with AIDS: } \\
8.4 \mathrm{mg} \text { BID } \\
\text { - CINV in adults failing conventional antiemetics: } \\
\text { I } 2.6 \mathrm{mg} / \mathrm{m}^{2} \text { per dose, not exceeding six doses/day }\end{array}$ \\
\hline Contraindications & - Hypersensitivity to dronabinol or sesame oil & $\begin{array}{l}\text { - Hypersensitivity to dronabinol or alcohol } \\
\text { - Patients on disulfiram- or metronidazole-containing } \\
\text { products within } 14 \text { days }\end{array}$ \\
\hline Bioavailability & $10 \%$ & $20 \%$ \\
\hline Onset of action (hours) & $\bullet 0.5-1$ & $\cdot 0.25$ \\
\hline Half-life (hours) & $\cdot 4$ & - 5.6 \\
\hline$C_{\max }(\mathrm{ng} / \mathrm{mL})$ & 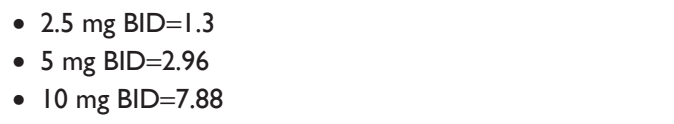 & - $2.1 \mathrm{mg} B I D=1.9$ \\
\hline$T_{\max }$ (hours) & $\begin{array}{l}\text { - } 2.5 \mathrm{mg} \mathrm{BID}=1.0 \\
\text { - } 5 \mathrm{mg} \mathrm{BID}=2.5 \\
\text { - } 10 \mathrm{mg} \mathrm{BID}=1.5\end{array}$ & - $2.1 \mathrm{mg} B I D=I .0$ \\
\hline Metabolism & \multicolumn{2}{|l|}{$\begin{array}{l}\text { - Liver: extensive first-pass } \\
\text { - CYP2C9 and CYP3A4 }\end{array}$} \\
\hline Drug interactions & \multicolumn{2}{|c|}{$\begin{array}{l}\text { - Inhibitors and inducers of CYP2C9a and CYP3A4 may affect the levels of dronabinol } \\
\text { I. Darunavir, atazanavir, ritonavir, and elvitegravir/cobicistat appear to potentially increase the levels of dronabinol, } \\
\text { whereas etravirine and efavirenz may potentially reduce the levels of dronabinol } \\
\text { 2. Monitor increased adverse drug events associated with dronabinol, as well as adequate appetite stimulation } \\
\text { - Highly protein-bound drugs: dronabinol is a highly protein-bound drug and may displace other protein-bound } \\
\text { drugs, increasing their exposure. Monitor the levels of warfarin, cyclosporine, and so on } \\
\text { - Other drugs thought to interact: disulfiram, fluoxetine, theophylline, barbiturates, benzodiazepines, amitriptyline, } \\
\text { amphetamines, cocaine, metronidazole, anticholinergics, and other CNS depressants }\end{array}$} \\
\hline Elimination & \multicolumn{2}{|l|}{$\begin{array}{l}-20 \% \text { feces } \\
-\sim 10 \%-15 \% \text { urine } \\
-<5 \% \text { unchanged }\end{array}$} \\
\hline Effects of food & $\begin{array}{l}\text { - Food appears to increase } C_{\text {max }}, t_{1 / 2}, A \cup C_{0-t} \text {, and } \\
A \cup C_{0-\infty} \text {, but slows how long it takes for dronabinol to } \\
\text { be detected in the plasma }\end{array}$ & $\begin{array}{l}\text { - With administration of a high-fat meal }(59 \mathrm{~g} \text { fat, } \\
950 \text { calories), there was a } 2.5 \text {-fold increase in } A \cup C_{0-\infty} \text {, } \\
\text { a } 5 \text {-hour delay in } T_{\max } \text {, and a } 20 \% \text { decrease in } C_{\max }\end{array}$ \\
\hline
\end{tabular}

Notes: ${ }^{~}$ For individuals with the CYP2C9 genetic polymorphism, clearance may be decreased with associated systemic effects increased. Monitor for increased adverse effects.

Abbreviations: AIDS, acquired immunodeficiency syndrome; $A \cup C_{0-\infty}$, area under the plasma concentration-time curve from time zero to infinity; $A \cup C_{0-{ }^{\prime}}$, area under the plasma concentration-time curve from time zero to the last measurable concentration; BID, twice daily; CINV, chemotherapy-induced nausea and vomiting; $C_{\text {max }}$, peak plasma concentration; CNS, central nervous system; CYP, cytochrome P450; PO, oral administration; $t_{1 / 2}$, half-life; $T_{\text {lag }}$, time to the first measurable concentration; $T_{\text {max }}$, time to maximum plasma concentration. 
under fed and fasted conditions $\left(\mathrm{T}_{\mathrm{lag}}, T_{\max }, C_{\max }, t_{1 / 2}, \mathrm{AUC}_{0-\mathrm{t}}\right.$, and $\mathrm{AUC}_{0-\infty}$ ) as well as the safety profile (Table 2 ). The two groups were also compared to a dronabinol capsule $5 \mathrm{mg}$ under fasted conditions.

Under fed conditions, the initial absorption was quicker with the oral solution when compared to the capsule by a difference of 1.87 hours. The time to detect dronabinol concentrations in individuals taking the oral solution was 15 minutes, whereas it took $\sim 2$ hours to detect concentrations in individuals taking the capsule formulation. In addition, under a fed state, all individuals who took dronabinol oral solution had detectable concentrations of dronabinol 30 minutes after dose administration. However, only $15 \%$ of all individuals who took the capsule registered detectable concentrations of dronabinol 30 minutes later. Based on these data, absorption of the oral solution would occur faster than the capsule formulation, allowing for a quicker onset of action. Furthermore, interindividual variability measured in dronabinol plasma concentrations was lower with the oral solution when compared to the capsule up to 4 hours after the doses had been administered. A common adverse drug event reported was headache $(3.8 \%$ of oral solution and $1.9 \%$ of capsules under fed state). Food appears to have a considerable effect on the pharmacokinetics of dronabinol. Under a fed state, individuals who were given dronabinol capsules appeared to have higher $C_{\max }, t_{1 / 2}, \mathrm{AUC}_{0-\mathrm{t}}$, and $\mathrm{AUC}_{0-\infty}$ than those who were given dronabinol capsules under fasting conditions. Euphoric mood was also reported in 3.8\% and $1.9 \%$ of the oral solution and capsules, respectively.

It is important to note that both studies were conducted in healthy individuals and may not truly predict pharmacokinetics in patients living with HIV/AIDS or cancer with or without concomitant use of antiretroviral therapy or chemotherapy. In addition, only one dose of the drug was given and, thus, may not reflect true steady-state data. Further studies that include these patient populations and multiple administration doses are warranted.

\section{Pharmacotherapy considerations}

Beyond efficacy and safety, the success of any drug therapy hinges on a patient's ability to adhere to the prescribed treatment. Aspects such as storage options, administration, doses per day, and formulation all affect the ease of effective use of pharmacotherapy. Dronabinol oral capsules need to be packaged in a well-closed container and kept in a cool environment. The capsules can be refrigerated, but should be protected from freezing. Patients who are allergic to sesame oil, glycerin, and gelatin may not use the capsule as they are co-formulated in this dosage form. Dronabinol oral capsules should be swallowed whole and should not be chewed in order to achieve full benefits. ${ }^{9}$

Dronabinol oral solution is supplied in a $5 \mathrm{mg} / \mathrm{mL}$ strength and comes with a $1 \mathrm{~mL}$ calibrated dosing syringe to ensure dosing accuracy. If the dose exceeds $5 \mathrm{mg}$, or $1 \mathrm{~mL}$, the dose will need to be divided. The calibrated dosing syringe should always be used when dosing oral dronabinol to ensure dosing accuracy. Each dose should be taken with 6-8 ounces of water. ${ }^{10}$ Dronabinol oral solution should be stored in the refrigerator until opened and then may be stored at room temperature for up to 28 days. Elderly patients may be more sensitive to the effects of dronabinol oral solution, and they experience increased neuropsychiatric and postural hypotensive effects. Therefore, a lower starting dose should be recommended in this population as well as in those unable to tolerate initial dosing recommendations (Table 2).

For patients experiencing CNS side effects (feeling high, dizziness, confusion, or somnolence), resolution typically occurs in 1-3 days and does not require a dosage reduction. For patients who continue to experience CNS side effects, dosing later in the day or near bedtime may reduce the incidence. In addition, the dose should be reduced if the patient continues to experience CNS side effects (Table 2).

The use of dronabinol oral solution is contraindicated in patients who report a previous hypersensitivity reaction to dronabinol or alcohol. In addition, patients taking disulfiram- or metronidazole-containing products within 14 days (or 7 days after completing treatment with dronabinol solution) should also avoid this solution since this product contains $50 \%$ dehydrated alcohol and 5.5\% propylene glycol. If these agents are used concomitantly, it may produce a disulfiram-like reaction (abdominal cramps, nausea, vomiting, headaches, and flushing).

As with dronabinol capsules, caution should be used in patients with an underlying psychiatric diagnosis such as mania, depression, or schizophrenia since dronabinol has been reported to exacerbate these symptoms. If the drug cannot be avoided, patients should be closely monitored for new or worsening psychiatric symptoms. ${ }^{10}$ Additionally, caution should be exerted in patients with seizures as this can lower the seizure threshold, in patients with a history of substance abuse with marijuana and/or alcohol due to the risk of abuse or misuse of this product, or in those operating machinery or driving a motor vehicle as this may impair their abilities. Paradoxical nausea, vomiting, or abdominal pain has been documented with dronabinol use. These effects are similar to cannabinoid hyperemesis syndrome as has been associated with chronic, long-term use. Dosage reduction or discontinuation should occur if the patient finds these effects intolerable. 
Safety data for dronabinol oral solution are based on studies performed with dronabinol capsules and include a combined total of 474 patients receiving dronabinol for AIDS-related weight loss or CINV compared to 135 placebo recipients. Patients were more likely to report a feeling of being "high" in the antiemetic trials (24\%) likely due to higher dosing requirements as compared to weight loss trials in patients with AIDS (8\%), as shown in Table 2.

\section{Conclusion}

Due to the lack of standardized definitions, the true incidence of anorexia and/or weight loss in HIV/AIDS or cancer is likely underestimated as well as undertreated. The use of oral dronabinol solution may provide an additional treatment option in patients experiencing anorexia and/or weight loss in HIV/AIDS or cancer. Oral dronabinol solution demonstrates lower interindividual variability as well as a quicker onset of action when compared to the capsule formulation. The interindividual variability seen among dronabinol users is believed to stem from the differences in excipients used in the dosage formulations. The capsule formulation uses a system that is based in sesame oil. Lipolysis has been shown to affect oil-based systems of drug delivery prior to absorption. The oral solution uses a hydroalcoholic formulation, which does not undergo lipolysis before it is absorbed. ${ }^{30}$ Lipolysis of the drug delivery system is thought to be the culprit of the interindividual variability; therefore, a drug not using an oil-based system is expected to have less variability as demonstrated in the case of dronabinol oral solution. ${ }^{8}$ This could be beneficial in patients unable to swallow an oral capsule or unwilling to inhale marijuana. With the legalization of medicinal and recreational marijuana, renewed interest and research should be conducted to evaluate the safety and efficacy of cannabis and dronabinol in these clinical settings to assess appetite stimulation.

\section{Disclosure}

The authors report no conflicts of interest in this work.

\section{References}

1. Badowski ME, Perez SE. Clinical utility of dronabinol in the treatment of weight loss associated with HIV and AIDS. HIV AIDS. 2016;8:37-45.

2. Badowski M, Pandit NS. Pharmacologic management of human immunodeficiency virus wasting syndrome. Pharmacotherapy. 2014;34(8): 868-881.

3. Mangili A, Murman DH, Zampini AM, Wanke CA. Nutrition and HIV infection: review of weight loss and wasting in the era of highly active antiretroviral therapy from the nutrition for health living cohort. Clin Infect Dis. 2006;42(6):836-842.

4. National Cancer Institute. Nutrition in Cancer Care (PDQ $\left.{ }^{\circledR}\right)$-Health Professional Version. Available from: https://www.cancer.gov/about-cancer/ treatment/side-effects/appetite-loss/nutrition-hp-pdq\#link/_23_toc. Accessed August 30, 2017.
5. Tong $\mathrm{H}$, Isenring $\mathrm{E}$, Yates $\mathrm{P}$. The prevalence of nutrition impact symptoms and their relationship to quality of life and clinical outcomes in medical oncology patients. Support Care Cancer. 2009;17(1):83-90.

6. Grotenhermen F. Pharmacokinetics and pharmacodynamics of cannabinoids. Clin Pharmacokinet. 2003;42(4):327-360.

7. National Cancer Institute. NCI Thesaurus. Available from: https:// ncit.nci.nih.gov/ncitbrowser/ConceptReport.jsp?dictionary=NCI_ Thesaurus\&ns=NCI_Thesaurus\&code $=$ C867. Accessed September 01, 2017.

8. Oh DA, Parikh N, Khurana V, Cognata Smith C, Vetticaden S. Effect of food on the pharmacokinetics of dronabinol oral solution versus dronabinol capsules in healthy volunteers. Clin Pharmacol. 2017; 9:9-17.

9. Marinol (dronabinol capsules) [package insert]. North Chicago, IL: AbbVie, Inc.; 2017.

10. Syndros (dronabinol oral solution) [package insert]. Chandler, AZ: Insys Therapeutics, Inc.; 2017.

11. Beal J, Olson R, Lefkowitz L, et al. Long-term efficacy and safety of dronabinol for acquired immunodeficiency syndrome-associated anorexia. J Pain Symptom Manage. 1997;14(1):7-14.

12. Beal JE, Olson R, Laubenstein L, et al. Dronabinol as a treatment for anorexia associated with weight loss in patients with AIDS. $J$ Pain Symptom Manage. 1995;10(2):89-97.

13. Lindan CP, Allen S, Serufilira A, et al. Predictors of mortality among HIV-infected women in Kigali, Rwanda. Ann Intern Med. 1992;116(4):320-328.

14. Guenter P, Muurahainen N, Simons G, et al. Relationships among nutritional status, disease progression, and survival in HIV infection. J Acquir Immune Defic Syndr. 1993;6(10):1130-1138.

15. Drugs@ @DA. Available from: https://www.accessdata.fda.gov/ scripts/cder/daf/index.cfm?event=overview.process \&ApplNo=018651. Accessed September 11, 2017.

16. Haney M, Gunderson EW, Rabkin J, et al. Dronabinol and marijuana in HIV-positive marijuana smokers: caloric intake, mood, and sleep. J Acquir Immune Defic Syndr. 2007;45(5):545-553.

17. Prentiss D, Power R, Balmas G, Tzuang G, Israelski DM. Patterns of marijuana use among patients with HIV/AIDS followed in a public health care setting. J Acquir Immune Defic Syndr. 2004;35(1):38-45.

18. Bedi G, Foltin RW, Gunderson EW, et al. Efficacy and tolerability of high-dose dronabinol maintenance in HIV-positive marijuana smokers: a controlled laboratory study. Psychopharmacology (Berl). 2010; 212(4):675-686.

19. Fox KM, Brooks JM, Gandra SR, Markus R, Chiou CF. Estimation of cachexia among cancer patients based on four definitions. J Oncol. 2009;2009:693458.

20. Tisdale MJ. Cachexia in cancer patients. Nat Rev Cancer. 2002; 2(11):862-871.

21. Parikh N, Kramer WG, Khurana V, Cognata Smith C, Vetticaden S. Bioavailability study of dronabinol oral solution versus dronabinol capsules in healthy volunteers. Clin Pharmacol. 2016;8:155-162.

22. Sallan SE, Cronin C, Zelen M, Zinberg NE. Antiemetics in patients receiving chemotherapy for cancer: a randomized comparison of delta9-tetrahydrocannabinol and prochlorperazine. N Engl J Med. 1980; 302(3): 135-138.

23. Meiri E, Jhangiani H, Vredenburgh JJ, et al. Efficacy of dronabinol alone and in combination with ondansetron versus ondansetron alone for delayed chemotherapy-induced nausea and vomiting. Curr Med Res Opin. 2007;23(3):533-543.

24. Chang AE, Shiling DJ, Stillman RC, et al. Delata-9-tetrahydrocannabinol as an antiemetic in cancer patients receiving high-dose methotrexate. A prospective, randomized evaluation. Ann Intern Med. 1979;91(6): 819-824.

25. Ungerleider JT, Andrysiak T, Fairbanks L, Goodnight J, Sarna G, Jamison K. Cannabis and cancer chemotherapy: a comparison of oral delta-9-THC and prochlorperazine. Cancer. 1982;50(4):636-645.

26. Plasse TF, Gorter RW, Krasnow SH, Lane M, Shepard KV, Wadleigh RG. Recent clinical experience with dronabinol. Pharmacol Biochem Behav. 1991;40(3):695-700. 
27. Nelson K, Walsh D, Deeter P, Sheehan F. A phase II study of delta9-tetrahydrocannabinol for appetite stimulation in cancer-associated anorexia. J Palliat Care. 1994;10(1):14-18.

28. Jatoi A, Windschitl HE, Loprinzi CL, et al. Dronabinol versus megestrol acetate versus combination therapy for cancer-associated anorexia: a North Central Cancer Treatment Group study. J Clin Oncol. 2002;20(2):567-573.

29. Strasser F, Luftner D, Possinger K, et al. Comparison of orally administered cannabis extract and delta-9-tetrahydrocannabinol in treating patients with cancer-related anorexia-cachexia syndrome: a multicenter, phase III, randomized, double-blind, placebo-controlled clinical trial from the Cannabis-In-Cachexia-Study-Group. J Clin Oncol. 2006;24(21):3394-3400.
30. MacGregor KJ, Embleton JK, Lacy JE, et al. Influence of lipolysis on drug absorption from the gastro-intestinal tract. Adv Drug Deliv Rev. 1997;25(1):33-46.

Therapeutics and Clinical Risk Management

\section{Publish your work in this journal}

Therapeutics and Clinical Risk Management is an international, peerreviewed journal of clinical therapeutics and risk management, focusing on concise rapid reporting of clinical studies in all therapeutic areas, outcomes, safety, and programs for the effective, safe, and sustained use of medicines. This journal is indexed on PubMed Central, CAS,
EMBase, Scopus and the Elsevier Bibliographic databases. The manuscript management system is completely online and includes a very quick and fair peer-review system, which is all easy to use. Visit http://www.dovepress.com/testimonials.php to read real quotes from published authors.

Submit your manuscript here: http://www.dovepress.com/therapeutics-and-clinical-risk-management-journal 